\title{
Anticipated Reductions in Tax Rates and Earning Management of Listed Companies: Evidence from China
}

\author{
Mo Bai (iD, Dandan Song, and Helin Li \\ Tianjin University of Commerce, Tianjin, China \\ Correspondence should be addressed to Helin Li; kevin2017@tjcu.edu.cn
}

Received 3 August 2021; Accepted 22 September 2021; Published 5 October 2021

Academic Editor: Daqing Gong

Copyright (c) 2021 Mo Bai et al. This is an open access article distributed under the Creative Commons Attribution License, which permits unrestricted use, distribution, and reproduction in any medium, provided the original work is properly cited.

\begin{abstract}
The effects of tax rate changes on corporations' earning management are not fully understood. As a transitional economy, China has listed companies with different ownership and special regulatory rules. We explore under the expectation of tax reduction whether there are differences in the way and degree of earnings management implemented by different types of companies. Our study shows that firms under the anticipation of tax reduction make use of earning management, including delaying sales, taking unusual incomedecreasing discretionary accruals, and so on, which leads to lower income in higher tax rate period. We find that private enterprises have more attention to reduce earning in the higher tax rate period than state-owned enterprises (SOEs), indicating that the ownership has effect on the extent of earning management. Moreover, under the specific regulations in Chinese stock market, we find that for those listed companies with negative net profit in the previous year, the priority is how to reverse losses rather than tax saving.
\end{abstract}

\section{Introduction}

The Tax Reform was announced by the ministry of Chinese finance in 2007, which would reduce tax rates of some corporations from a maximum of $33 \%$ to $25 \%$ in the following accounting period (before the Tax Reform, there are blends of tax rates in various types of Chinese corporations; the maximum tax rate is $33 \%$, while the tax preference is available for the corporations in the special economic zone (SEZ) and overseas-funded enterprises in the high technology industry; according to 2008 annual reports of corporations that enjoyed tax preference in 2007 (aggregate 320 ), most of them (209 corporations) continue to keep tax preference in 2008 , so we merely examine the earning management of corporations in anticipation of tax reduction in this paper). This precommitment to lower rates enabled corporate managers to plan, knowing that rates were falling, and provided us a powerful setting to assess firms' willingness of earning management in 2007, a higher tax rate period, deferring sales and earnings to the next.

On the other hand, Scholes et al. [1] suggest that managers are reluctant to bear the perceived costs of reporting reduced income. In addition, postponing revenue recognition or accelerating expense recognition may increase nontax costs. As Boynton et al. [2] pointed out, accelerating deductible expenditures may reduce operating efficiency, or customer relations may deteriorate from intentional delays in shipping finished goods, not to mention additional inventory holding costs. Hence, the managers with anticipated reductions in tax rates should trade off between costs of extra loss and benefits of tax saving from earning management. According to the study of Jeong and Choi [3], the decision making of listed companies will be affected by cognitive bias when tax policies change.

This study tests whether Chinese firms affected by the Tax Reform of 2007 managed their 2007 earnings to reduce their tax liabilities. We use the expectation model of Boynton et al. [2] to estimate the persistent accrual. Then, we take the differences between the expected persistent accrual and observed real accrual as the proxy of earning management. The empirical evidences indicate that the corporations with anticipated reductions in tax rates managed their 2007 earnings by taking unusual income-decreasing discretionary accruals. Furthermore, compared with state-owned corporations, private corporations achieved such tax saving with greater motivation. Besides, net losses (NLs) of the previous 
year that would be offset from the current taxed income have a negative effect on the earning management motivated by tax saving. These results have implications for marketing, tax, and financial policy and provide information useful to investors and customers.

The remainder of this article is organized as follows. Section 2 discusses previous research. Section 3 develops testable hypotheses in the context of our empirical framework. In Section 4, we outline the sample selection procedure and describe the measurement of earning management. Sections 5 and 6 report the results and sensitive tests, respectively. The final section summarizes the main findings.

\section{Literature Review}

Previous research studies find that mobile taxable income flows toward low-tax jurisdictions, either through the movement of real operations or through accounting-based income shifting $[4,5]$. Besides income shifting, earning management, as another means of tax saving, is also found in the scenario of tax rate changes. The 1986 Tax Act in US, which reduces corporate tax rates from a maximum of $46 \%$ to $34 \%$ over a period of two years, provides the researchers a good opportunity. Using the model in Foster [6], Scholes et al. [7] showed that firms could defer sales in anticipation of tax rate declines. Boynton et al. [2] found evidence that firms without net operating losses (NOLs) and foreign tax credits (FTCs) managed their 1987 earnings by taking unusual income-decreasing discretionary accruals. Guenther [8] extended Scholes et al.'s model [7] to include proxies for financial reporting costs, providing evidence that firms with higher leverage ratios (a proxy for financial reporting costs) are less willing to manage marketing and report lower income.

As a whole, related empirical research proves that the 1986 Tax Act leads firms to manage earning and report lower income in order to reduce their tax liability in the previous accounting period of tax reduction.

Chinese corporations also experienced tax rate change in 2002. Unlike the anticipated reductions, tax preference was canceled for some Chinese listed companies from 2002. Dai and Yin [9] examine when Chinese listed companies get to know in 2000 that the preferential tax policy would be abolished in 2002, will they increase their reported incomes and earnings in 2000 and 2001, and reduce the amount reported in 2002 accordingly? But there is no evidence found. They attribute it to the low ability of tax planning for Chinese companies. Wu and Yue [10] reported that firms affected by tax increment increased their leverage ratios to achieve the benefit of tax shield.

This study differs from prior research in three ways. First, we test whether the Chinese companies manage their earnings in order to get tax saving in anticipation of tax reduction. Second, according to transitional economy backgound, the ownership of companies is considered to test whether different ownerships affect the extent of earning management. Third, considering the specific regulations in Chinese stock market, we test, for those listed companies with negative net profit in2006, the priority of them is how to avoid losses for two consecutive accounting periods or getting tax saving in 2007?

\section{Hypothesis}

Modigliani and Miller [11] believe the tax saving is beneficial to adding firm' value. Therefore, firms with anticipation of tax reduction have motivation to increase the firm value by managing marketing and reporting lower income in the period of high tax rate, deferring sales and earnings to the next accounting period of lower tax rate. In addition, the motivation has been proved by empirical evidences $[2,7,12]$.

This gives rise to hypothesis 1 .

$\mathrm{H} 1$ : companies with anticipated reductions in tax rates managed their 2007 marketing and reported a lower income by taking unusual income-decreasing discretionary accruals.

The Chinese setting is unique because there is evident heterogeneity in ownership type across listed companies. All the companies can be divided into two distinct groups: stateowned enterprises (SOEs) and private enterprises. This allows us to devise sharper and more powerful tests by examining the effects of different ownership types on the extent of earning management motivated by tax saving. In addition to creating shareholder wealth, SOEs are politically favored [13], while whether managers in the SOEs can achieve the growth objectives brought forward by their superiors or not often determines their promotion. Therefore, they have more intentions to report higher income in 2007 at the cost of losing tax saving and impairing the benefits of shareholders. Compared with managers in the SOEs, ones in private companies may pay more attention to the benefits of shareholders rather than the growth objection of superiors, thus resulting in a stronger extent for earning management motivated by tax saving.

This gives rise to hypothesis 2 .

$\mathrm{H} 2$ : facing the anticipation of tax reduction, the extent of earning management in the higher tax rate period is stronger for private companies.

Under the specific regulations in Chinese stock market, if the earnings disclosed by the company are negative for two consecutive years, it will face special treatment (ST), which will lead to economic consequences such as stock trading restrictions in the secondary market and even delisting. Moreover, according to the Chinese tax law, NLs (net losses) of the previous period are allowed to be offset from the current taxed income. That is to say, the previous NL has the same effect on tax saving for the companies. Therefore, for those listed companies with negative net profit in the previous year, the priority is how to reverse losses rather than tax saving. This gives rise to hypothesis 3 .

H3: for the companies with anticipated reductions in tax rates, the motivation of earning management in higher tax rate period may be counteracted by the previous NLs. 


\section{Data and Methodology}

4.1. Data. We take the listed companies in the manufacturing industry as our sample. Because the financial data within a five-year interval (2003-2007) are needed in our research, firstly, we identify companies in the manufacturing industry whose IPO date is before the Dec 31, 2004 (Chinese listed companies disclose the financial data in the previous year of the IPO; therefore, our deadline is 2004 rather than 2003; we took the companies in the manufacturing industry as our sample because more than 60 per listed companies are manufacturing ones, so there are not enough samples available in the other industries, especially the ones whose IPO dates are before Dec 31, 2004; anyway, the dominant situation of manufacturing firms makes sense for our sample selection). Secondly, 90 "ST (special treatment)" companies are dropped off from our samples ("ST" companies are the ones whose net income is continuously negative in the two years; it is a unique regulation system in China, whose intention is to delete the firms with continuously poor performances from the listed companies; the bargaining, trading, and financing of the "ST" companies are strictly limited; therefore, those firms are usually deleted from the sample (see Dai and Yin [9])). Finally, 15 companies that changed their industry within a five-year interval (2003-2007) and 5 manufacturing companies whose second industry is not available in Wind Database are deleted. The sample selection procedure yields a total of 639 firms.

4.2. The Measure of Earning Management. Taxed income is needed in order to test the earning management motivated by tax saving. Unfortunately, it is not available in the annual report of Chinese listed company. Although taxed income and book income often differ in revenue recognition and other important concerns, tax plans often result in reporting lower book income [14]. Based on the reason, we followed the Dai and Yin [9] and Manzon [12], taking book income as the proxy of taxed income.

Prior research (e.g., Zmijewski and Hagerman [15] and Warfield et al. [16]) has demonstrated that variables such as size, debt covenant, and earning fluctuation are important for explaining the earning management. In order to test whether there is earning management motivated by tax saving, it is necessary to control those variables. While Boynton et al. [2] exaimes whether firms affected by the U.S. corporate alternative minimum tax (AMT) managed their 1986 and 1987 earnings to reduce their tax liabilities. In their model, any persistent accrual can be predicted by economic variables. The remaining unexpected accruals are "book only" in the sense that they are not predicted by the economic control variables. In their opinion, book-only accruals are used by managers to get the tax saving. Considering the similar background, we take the expectation model to estimate the unexpected accruals. However, the total accruals [17] is substituted by the current accruals [18] in our research. Two reasons are presented as follows. First, besides the Tax Reform, the new accounting rules were enforced in 2007 in Chinese listed companies, which affected the performance of listed companies greatly [19]. Compared with the current accruals, the total accruals are vulnerable in the face of the changes. So, we take the current accrual as substitution to make the effect of new accounting rules minimum. Second, one significant difference of Chinese tax reform from US is that the interval between announcement date and enforcement date is rather short. The reform was put into force 9 months after it had been announced in China. Therefore, the time left for managers to plan is not so much, while as Teoh et al. [18] pointed out, it is convenient for the managers to use current accruals rather than total accruals to manage earning.

We use 2004-2006 as the base period to develop measures for the test period of 2007.

Current accruals may be calculated as follows:

$$
\begin{aligned}
\mathrm{CA}_{t}= & \Delta\left(\text { current asset }_{t}-\text { cash }_{t}\right) \\
& -\Delta(\text { current liability } \\
t & \left.- \text { current maturities of long }- \text { term }_{t}\right),
\end{aligned}
$$

where $t$ represents the year $t, \Delta$ (currentasset ${ }_{t}-$ cash $\left._{t}\right)$ and $\Delta$ (current liability - current maturities of long-term $_{t}$ ) indicate the corresponding amount difference between year $t$ and year $t-1$.

Current assets refer to accounts receivable, notes receivable, prepaid accounts and inventory except cash. While current liability includes accounts payable, notes payable and accounts received in advance except current maturities of long-term liabililty. If firms manage their marketing motivated by tax saving in 2007, they would put off product sales or revenue recognition, resulting in reporting a lower accounting receivables and note receivables and leading to a lower CA number.

According to the definition of second industry given by China Securities Regulatory Commission, our samples are divided into 8 subsamples. Within each second industry subsample, every firm was further classified as "large" if 2006 total assets were at least $80 \%$ of the 2006 total assets of the fifth largest firm in the second industry. A "small" firm had 2006 total assets equal to or less than $10 \%$ of the total assets of the fifth largest firm in the industry. Based on these classifications, binary variables LARGE or SMALL were set equal to one if the firm met the definition, zero otherwise.

After calculating the current accruals from 2004 to 2006 by formula (1), regression analysis (formula 2) is used to examine relationship between dependent variable and independent variables, estimating the Intercept $(\alpha 0)$ and the coefficient $(\alpha 1, \alpha 2$, and $\alpha 3)$ of different independent variables. In order to control the influence of company size on the degree of earnings management, companies with total assets of the top five in the industry or more than $80 \%$ of the fifth largest companies in 2006 are defined as "large" companies. Companies with total assets equal to or less than $10 \%$ of the fifth largest companies in the industry in 2006 are defined as "small" companies. According to this division, when the company meets the above criteria, the corresponding dummy variable "LARGE" or "SMALL" is set to 1, otherwise it is 0 . Both accounting variables were scaled by 
TABle 1: Description of industry group sample used to estimated current accruals.

\begin{tabular}{|c|c|c|c|}
\hline Industry group & No. of obs. & F & Adj.R2 \\
\hline Electrical & 38 & $3.0840^{* * *}$ & 0.4230 \\
\hline Textiles and furs & 49 & $1.5673^{* *}$ & 0.1723 \\
\hline Machinery, equipment, and instrument & 178 & $22.4750^{* * *}$ & 0.2396 \\
\hline Ferrous and nonferrous metals & 100 & $15.2224^{* * *}$ & 0.1271 \\
\hline Petroleum, chemicals, and plastics & 122 & $12.4326^{* * *}$ & 0.0881 \\
\hline Food and drink & 51 & $18.7708^{* * *}$ & 0.1053 \\
\hline Pharmaceutical & 81 & $13.7592^{* * *}$ & 0.1077 \\
\hline Paper making and printing & 20 & 0.9879 & -0.0540 \\
\hline Total & 639 & & \\
\hline
\end{tabular}

***, ${ }^{* *}$, and ${ }^{*}$ denote significance at $0.01,0.05$, and 0.10 levels, respectively.

TABLe 2: Definition of variables.

\begin{tabular}{lcc}
\hline Variable & Symbol & Description \\
\hline $\begin{array}{lcc}\text { Dependent variable } \\
\text { DAP }\end{array}$ & Earning management motivated by tax saving. \\
$\begin{array}{l}\text { Explanatory } \\
\text { variable }\end{array}$ & Tax & Dummy variable, which is equal to 1 if the tax rate of companies in 2008 is less than that of in 2007, 0, \\
& Control & Dummy variable, which is equal to 1 if the controlling shareholders are non-state, 0, otherwise. \\
& NI06 & Dummy variable, which is equal to 1 if the net income of the firm in 2006 is negative, 0, otherwise. \\
\hline
\end{tabular}

lagged assets. The regression was run using pooled data within each industry. The slopes were the pooled crosssectional time-series industry slopes. The estimated equation for each industry (expressed in terms of the $i$ th firm) is

$$
\begin{aligned}
\frac{C A_{i, t}}{A_{i, t-1}}= & \alpha_{0}+\alpha_{1} \frac{\Delta \text { Sales }_{i, t}}{A_{i, t-1}}+\alpha_{2} \frac{\Delta \text { Sales }_{i, t}}{A_{i, t-1}} \cdot \text { LARGE } \\
& +\alpha_{3} \frac{\Delta \text { Sales }_{i, t}}{A_{i, t-1}} \cdot \text { SMALL }+\varepsilon_{i, t},
\end{aligned}
$$

where $A$ represents firm assets. Although a priori expectation for the sign of the coefficient of the change in sales is positive, the results are mixed. There is no a priori expectation about the sign of the coefficients for LARGE and SMALL. Table 1 lists the 8 second industry groups included in the study along with some summary statistics (when $F$ statistic is not significant, the estimate of total accruals reduces to the firm-specific mean current accrual during the base period).

The pooled industry slopes were then used to forecast scaled nondiscretionary current accruals (NCAs) for 2007. The general form for each firm $(i)$ in each year $(t)$ is

$$
\mathrm{NCA}_{i, t}=\mu_{i, t}+\left(a_{1}+a_{2} \mathrm{LARGE}+a_{3} \mathrm{SMALL}\right) \frac{\Delta \text { Sales }_{i, t}}{A_{i, t-1}}
$$

where $a_{i}$ is the estimate of $\alpha_{i}$. The difference between the observed scaled current accruals and the forecast was taken as the discretionary accrual proxy (DAP scaled):

$$
\mathrm{DAP}_{i, t}=\mathrm{CACC}_{i, t}-\mathrm{NCA}_{i, t} .
$$

\section{Empirical Results}

We test the hypotheses put forward in Section 3 by partitioning the samples and attempt to explain DAP by a regression of DAP on independent binary variables. The binary variable for a partition will equal one if the characteristics of the firm place it in that partition. A regression coefficient for a binary variable represents the difference between the mean of that partition and the intercept. Table 2 reports the quantity distribution of different types of companies. The model we estimate is

$$
\begin{aligned}
\text { DAP }= & \beta_{0}+\beta_{1} \text { Tax }+\beta_{2} \text { Control }+\beta_{3} \text { Control } \bullet \text { Tax } \\
& +\beta_{4} N I 06+\beta_{5} \text { NI06•Tax. }
\end{aligned}
$$

The coefficient of tax is $\beta_{1}$, which measures the mean difference of DAP between the firms with anticipation of tax reduction and the ones without it. $\mathrm{H} 1$ predicts that $\beta_{1}<0$.

Among the other coefficients, we are primarily interested in $\beta_{3}$ and $\beta_{5}$. $\beta_{3}$ reflects the difference in the level of DAP between SOEs and private ones, both of which are under the anticipation of tax reduction. $\mathrm{H} 2$ predicts that $\beta_{3}<0$, namely, the extent of taking unusual income-decreasing discretionary accruals is stronger for private companies, while $\beta_{5}$ represents the difference of DAP between the firms, in the same tax falling expectation, with NLs in 2006 and the ones without it. $\mathrm{H} 3$ predicts that $\beta_{5}>0$. This means that the motivation of taking unusual income-decreasing discretionary accruals in the higher tax rate period may be counteracted by the previous NLs.

Table 4 reports the results of the multivariate regression, which is supportive of our hypothesis. The coefficient estimates of both tax and control* tax are negative and significant at the ten percent level. These negative estimates suggest that earning management is associated with the anticipated tax reduction. Companies tend to report lower income in higher tax rate period, while private enterprises take more earning management in the higher tax rate period than state-owned enterprises (SOEs). The coefficient of the "NI06* tax" is also consistent with our hypothesis, indicating that the listed companies 
TABle 3: The quantity distribution of different types of companies.

\begin{tabular}{lcccccccc}
\hline Partitioning firms & $\operatorname{Tax}=1$ & $\mathrm{Tax}=0$ & Control $=1$ & Control $=0$ & NI06=1 & NI06=0 & Tax $=1$ and control=1 & Tax $=1$ and NI06=1 \\
\hline No. of obs. & 299 & 330 & 202 & 437 & 51 & 588 & 112 & 31 \\
\hline
\end{tabular}

TABLE 4: The empirical results of portioned model.

\begin{tabular}{lcccccc}
\hline & Intercept & Tax & Control & Control ${ }^{*} \operatorname{tax}$ & NI06 & NI06* tax \\
\hline Expected sign & $?$ & - & $?$ & - & $?$ & + \\
Coefficient & -0.024 & -0.074 & 0.047 & -0.075 & 0.053 & 0.161 \\
Std error & 0.055 & 0.043 & 0.037 & 0.048 & 0.057 \\
$T$ value & 0.667 & $-1.722^{*}$ & 1.273 & $-1.736^{*}$ & 0.938 & 0.080 \\
\hline
\end{tabular}

$F$ statistic (H0: all model parameters (expect the intercept) are zero): $3.670\left(p=0.002^{* * *}\right)$. Adj.R2 $=0.021 . * * *, * *$, and $*$ denote significance at $0.01,0.05$, and 0.10 levels, respectively.

with negative net profit in the previous year are primarily concerned with how to reverse losses rather than tax saving.

In order to make our conclusions robust, sensitivity tests are performed as follows. First, outliers are deleted by winsorization. Then, the subsamples in paper making and printing industry, whose $F$ statistics are not significant, are dropped off. The results continue to support three hypotheses proposed above.

In addition, the total accrual, calculated by Johns model [17], is used in our expectation model. But the results merely support $\mathrm{H} 1$ at the ten percent level. In our opinion, the noises included by the total accruals impair the conclusion.

\section{Conclusion}

This paper explores the relevance of anticipated tax reduction and the earning management motivated by tax saving in Chinese listed companies. Empirical results present that the firm with anticipation of tax reduction takes unusual income-decreasing discretionary accruals in the higher tax rate period to get tax saving, which shows the tax planning of the Chinese listed companies. While knowing that rates were falling, private companies take more unusual income-decreasing discretionary accruals in the higher tax rate period than SOEs, indicating that the ownership of the firm has effect on the achievement of value maximum. Besides, the motivation of taking unusual income-decreasing discretionary accruals in the higher tax rate period is counteracted by the previous NLs. Our finding helps to understand the differences in earning management behavior of different companies under the expectation of lower tax rates in transition economies [20]. The possible research direction in the future is whether the capital market will identify earning management behavior and whether the earning response coefficient of private companies reporting lower earnings is different from that of state-owned companies.

The results of this study should be considered in light of the following two limitations. First, the number of observations prevents us from constructing a longer base period in the expectation model, which results in Adj.R2 in Table 1 being not high, reducing the explaining power of the expectation model. Second, although we have adopted current accruals to control the effect of accounting rule reform, our results may still suffer from an endogeneity bias.

\section{Data Availability}

All the data in this paper are from the Wind Database.

\section{Conflicts of Interest}

The authors declare that they have no conflicts of interest.

\section{Acknowledgments}

This research has been supported by the project with the title "Research on better Safeguarding China's national tax interests under the background of international competition of taxing right of digital economy" (project no. 20BGJ031), which was funded by National Office for Philosophy and Social Sciences.

\section{References}

[1] M. S. Scholes, G. P. Wilson, and M. A. Wolfson, "Tax planning, regulatory capital planning, and financial reporting strategy for commercial banks," Review of Financial Studies, vol. 3, no. 4, pp. 25-50, 1990.

[2] C. E. Boynton, P. S. Dobbins, and G. A. Plesko, "Earnings management and the corporate alternative minimum tax," Journal of Accounting Research, vol. 30, pp. 131-151, 1992.

[3] S. Jeong and I. Choi, "Cognitive bias in decision making according to change of tax policy: an exploratory study," Journal of System and Management Sciences, vol. 9, no. 4, pp. 127-137, 2019.

[4] J. Slemrod, "Income creation or income shifting? behavioral responses to the tax reform act of 1986," The American Economic Review, vol. 85, no. 2, pp. 175-180, 1995.

[5] B. M. Williams, "Multinational tax incentives and offshored U.S. jobs," The Accounting Review, vol. 93, no. 5, pp. 293-324, 2018. 
[6] G. Foster, "Quarterly accounting data: time-series properties predictive-ability results," The Accounting Review, vol. 52, pp. 1-21, 1977.

[7] M. S. Scholes, G. P. Wilson, and M. A. Wolfson, "Firms' response to anticipated reductions in tax rates: the tax reform act of 1986," Journal of Accounting Research, vol. 30, pp. 6185, 1992.

[8] D. Guenther, "Earnings management in response to corporate tax rate changes: evidence from the 1986 tax reform act," The Accounting Review, vol. 69, no. 1, pp. 230-247, 1994.

[9] D. Dai and L. Yin, "The behavior choice of the listed companies suffering tax incensement," Contemporary Finance \& Economics, vol. 2, pp. 114-118, 2005, in Chinese.

[10] L. Wu and H. Yue, "Tax rate adjustment and capital structure alteration," Management World, vol. 11, pp. 111-127, 2006, in Chinese.

[11] F. Modigliani and M. Miller, "Corporate income taxes and the cost of capital: a correction," The American Economic Review, vol. 53, pp. 433-443, 1963.

[12] G. B. Manzon JR., "Earnings management of firms subject to the alternative minimum tax," Journal of American Taxation Association, vol. 14, pp. 88-111, 1992.

[13] S. Green, The Privatization Two-Step at China's Listed Firms Stanford Chartered Bank (Hong Kong) Limited, Hong Kong, China, 2004.

[14] D. A. Shackelford and S. Terry, "Empirical tax research in accounting," Journal of Accounting and Economics, vol. 31, pp. 321-387, 2001.

[15] M. Zmijewski and R. Hagerman, "An income strategy approach to the positive theory of accounting standard setting choice," Journal of Accounting and Economics, vol. 3, pp. 129-149, 1981.

[16] T. D. Warfield, J. J. Wild, and K. L. Wild, "Managerial ownership, accounting choices and in formativeness of earnings," Journal of Accounting and Economics, vol. 20, pp. 61-91, 1995.

[17] J. Johns, "The effects of foreign trade regulation on accounting choices," Journal of Accounting Research, vol. 29, pp. 193-228, 1991.

[18] S. H. Teoh, T. J. Wong, and G. Rao, "Are accruals during initial public offerings opportunistic?" Review of Accounting Studies, vol. 3, pp. 175-208, 1998.

[19] F. Zhang, "The factors influence the performance of listed companies," Finance and Accounting Research, vol. 6, pp. 54-56, 2008, in Chinese.

[20] B. Mo and F. Yue, "Anticipated reductions in tax rates and earning management of listed companies: evidence from China," in Proceedings of the 2009 International Symposium on Marketing Management, 2009. 